\title{
Pelatihan Penggunaan Microsof Power Point dalam Meningkatkan Keterampilan Menyajikan Presentasi yang Menarik dan Interaktif
}

\author{
Gerry Sastro $^{1}$, Yulianti Rusdiana ${ }^{2}$, Irvana Arofah ${ }^{3}$, Fani Oktaviani ${ }^{4}$, Anita Fujia ${ }^{5}$, Dhea Rezky \\ Febrianty $^{6}$, Novita Putri Amir ${ }^{7}$, Intan Idaman Halawa ${ }^{8}$ \\ Matematika, FMIPA, Universitas Pamulang, Indonesia ${ }^{1,2,3,4,5,6,7,8}$ \\ E-mail : dosen00544@unpam.ac.id ${ }^{1}, \underline{\text { dosen00868@unpam.ac.id }}{ }^{2}, \underline{\text { dosen00351@unpam.ac.id }}{ }^{3}$, \\ fanioktaviani63@gmail.com ${ }^{4}$, fujia78@gmail.com ${ }^{5}$, deafebrianty20@gmail.com6 \\ novitaputriamir@gmail.com ${ }^{7}$, intanhalawa2@gmail.com ${ }^{8}$
}

\begin{abstract}
Abstrak
Era industri 4.0 dan di masa pandemi, peserta didik dituntut untuk selalu aktif dan produktif mengembangkan potensinya. Perlunya pelatihan Ms power point bagi anak asuh di panti asuhan adalah untuk memperluas ilmu yang diperoleh pada Pendidikan formal sehingga dapat memperkaya imajinasi mereka saat membuat materi presentasi. Kedua, ajak mereka untuk saling percaya di depan teman-teman dan siswa senior mereka untuk membangun kepercayaan diri mereka jika mereka perlu menunjukkan identitas mereka di depan umum di masa depan. Tujuan dilaksanakannya pelatihan Ms Power Point bagi siswa SMA Yayasan Otto Iskanar Dinata adalah untuk meningkatkan wawasan dan pengetahuan siswa SMA Yayasan Otto Iskandar Dinata, memperbaiki kesalahan dalam presentasi dan dapat menggunakan Ms Power Point sebagai media presentasi. Pelatihan dilakukan dalam 3 (tiga) tahap. Pertama, penyampaian materi tentang pembuatan media presentasi dan penggunaan power point yang menarik.. Kedua, pelatihan membuat presentasi yang menarik dan interaktif. 3. Simulasikan presentasi, berbicara dengan percaya diri di depan umum. Dengan pelatihan bagaimana menggunakan Microsoft Powert Point untuk melatih keterampilan peserta didik dalam menyampaikan presentasi yang indah dan intraktif, ini adalah langkah yang tepat untuk meningkatkan motivasi belajar.
\end{abstract}

Kata kunci: pelatihan komputer, microsoft power point, pengabdian masyarakat

\section{Abstract}

The industrial era 4.0 and during the pandemic, students are required to always be active and productive in developing their potential. The need for Ms power point training for foster children in orphanages is to expand the knowledge gained in formal education so that they can enrich their imagination when making presentation materials. Second, get them to trust each other in front of their friends and senior students to build their confidence if they need to show their identity in public in the future. The objectives of the Ms Power Point training for Otto Iskanar Dinata Foundation SMA students are to increase the insight and knowledge of Otto Iskandar Dinata Foundation SMA students, to correct errors in presentations, can use Ms Power Point as a presentation media. The training is carried out in 3 (three) stages. First, the delivery of material on making presentation media and using interesting power points. Second, training on making interesting and interactive presentations. 3. Simulate a presentation, speak confidently in public. With training on how to use Microsoft PowerPoint to train students' skills in delivering beautiful and interactive presentations, this is the right step to increase learning motivation.

Keywords: computer training, microsoft power point, community service

Copyright (c) 2021 Gerry Sastro, Yulianti Rusdiana, Irvana Arovah, Fani Oktaviani, Anita Fujia, Dhea Rezky Febrianty, Novita Putri Amir, Intan Idaman Halawa

$\triangle$ Corresponding author

Address : Jalan Raya Puspitek/Kampus Unpam 2 Tower B L.7

ISSN 2721- 9224 (Media Cetak)

Email : dosen00544@unpam.ac.id

ISSN 2721- 9216 (Media Online)

DOI : https://doi.org/10.31004/abdidas.v2i4.299 
726 Pelatihan Penggunaan Microsof Power Point dalam Meningkatkan Keterampilan Menyajikan Presentasi yang Menarik dan Interaktif - Gerry Sastro, Yulianti Rusdiana, Irvana Arovah, Fani Oktaviani, Anita Fujia, Dhea Rezky Febrianty, Novita Putri Amir, Intan Idaman Halawa

DOI: https://doi.org/10.31004/abdidas.v2i4.299

\section{PENDAHULUAN}

Sistem pendidikan saat ini mengalami perubahan yang sangat dramatis. Ini karena pandemi Covid-19, yang membutuhkan pembelajaran online alih-alih pelajaran di kelas. Pendidikan harus dilakukan dalam sistem online yang lengkap (Ilmadi et al., 2020). Menetapkan kedaruratan kesehatan masyarakat untuk penyakit Covid-19 berdasarkan Keputusan Presiden Nomor 11 Tahun 2020, Keputusan Menteri 03/KB/2020, 612 Tahun 2020, HK.01.08/Menquez/502/2020, 119/4536/ SJ terpapar pandemi Covid-19 dan akan melakukan pembelajaran offline yang hanya bisa dilakukan dari area zona hijau dan kuning. Selebihnya pembelajaran harus dilakukan secara online.

Sebelumnya, pembelajaran online tidak dilakukan dalam waktu bersamaan, namun karena pengaruh COVID-19, pembelajaran online diharuskan dilakukan pada waktu yang bersamaan (Sun et al., 2020). Memikirkan waktu, tempat serta jarak menjadi isu besar saat ini (Kusuma \& Hamidah, 2020). Oleh sebab itu, pembelajaran online menjadi salah satu pilihan serta solusi untuk mengatasi permasalahan belajar tatap muka. Hal ini menjadi tantangan bagi seluruh pemangku kepentingan dan tingkat pendidikan untuk tetap aktif belajar, meski sekolah diliburkan (Herliandry et al., 2020).

Pada era indrustri 4.0, serta pada masa pandemi peserta didik dituntut untuk selalu aktif dan produktif dalam mengembangkan potensi yang mereka miliki. Perlunya menghadirkan sistem pembelajaran yang inspiratif, interaktif dan menyenangkan, menantang, memotivasi siswa untuk berpartisipasi aktif, serta memberikan peluang yang cukup bagi prakarsa, kreativitas, dan kemandirian sesuai dengan bakat, minat, serta perkembangan fisik dan psikologis siswa adalah dinyatakan dalam PERMEN No. 19 Th 2005 pasal 19 ayat 2, Pasal 40 ayat 2 Undang-Undang nomor 20 Tahun 2003 menyatakan bahwa pendidik dan tenaga kependidikan berkewajiban menciptakan suasana pendidikan yang bermakna, menyenangkan, kreatif, dinamis, dan dialogis. Juanita dkk., 2019)

perlunya pelatihan Ms Powert Point bagi peserta didik di Panti Asuhan adalah untuk menambah ilmu yang mereka peroleh di sekolah formal sehingga dapat memperluas imajinasi mereka dalam menyampaikan materi presentasi. Kedua, membiasakan mereka untuk berani tampil di depan umum atau siswa yang lebih tua sehingga akan meningkatkan confident mereka jika di kemudian hari harus kembali diminta tampil di depan umum.

Beberapa permasalahan yang dijumpai dilapangan dalam hal ini pada peserta didik yang ada di panti asuhan Yayasan Otto Iskandar Dinata, yaitu, pertama. Peserta didik tingkat SMA yang ada di Yayasan otto Iskandar Dinata, dalam mempresentasikan ide/gagasan mereka masih menggunakan cara yang konvensional yaitu dengan menggunakan papan tulis, karton dan sejenisnya. yang jelas itu dirasa kurang menarik, sementara, dengan menggunakan media presentasi yang menarik akan membuat suasana menjadi lebih hidup. Kedua, Peserta didik Yayasan Otto 
727 Pelatihan Penggunaan Microsof Power Point dalam Meningkatkan Keterampilan Menyajikan Presentasi yang Menarik dan Interaktif - Gerry Sastro, Yulianti Rusdiana, Irvana Arovah, Fani Oktaviani, Anita Fujia, Dhea Rezky Febrianty, Novita Putri Amir, Intan Idaman Halawa

DOI: https://doi.org/10.31004/abdidas.v2i4.299

Iskandar Dinata, dalam melaksanakan kegiatannya tidak didukung dengan teknik presentasi yang memadai, sehingga kurang maksimal serta kurang menarik minat peserta yang lain.

Tujuan dari pelaksanaan pelatihan penggunaan Microsoft Power Point kepada peserta didik tingkat SMA yang ada di Yayasan Otto Iskanar Dinata adalah untuk menambah wawasan dan pengetahuan peserta didik tangkat SMA yang ada di Yayasan Otto Iskandar Dinata, memperbaiki kekeliruan yang dilakukan pada saat presentasi, dan mampu menggunakan Microsoft Power Point dengan maksimal sebagai media presentasi.

\section{METODE}

Kegiatan pelatihan ini dilaksanakan selama 1 hari yaitu tanggal 15 April 2021, bertempat di Panti Asuhan Yayasan Otto Iskandar Dinata. Pelatihan dilakasakan dalam 3 (tiga) tahapan, Pertama, pemaparan materi tentang pembuatan media presentasi serta penggunakan power point yang menarik. Pada tahap ini, materi disampaikan oleh Gerry Sastro yang sekaligus ketua pengabdi. Kedua demontrasi dalam pembuatan presentasi menarik serta interaktif, di tahapan ini dikoordinir oleh Irvana Arofah. Ketiga simulasi cara menyampaikan informasi, berbicara di depan umum dengan confident. Pada tahap ini dikoordinir oleh Yulianti Rusdiana.

Pada tahapan yang pertama, peserta didik pelatihan diinformasikan tentang pentingnya soft skill presentasi dengan Ms Powert Point dalam kehidupan sehari-hari, terutama dalam pengajaran, presentasi tentang diri. Penyajiannya tidak terbatas pada ilmu murni, tetapi juga dapat berkaitan dengan masalah umum atau membuat infografis tentang kondisi sosial yang berkembang saat ini.

Tahap ke-2 peserta diperkenalkan dengan software power point serta penggunaan nya. Memberikan pengetahuan ini dengan supaya punya konsep dasar tentang teknik penggunaan Ms. Power Point. Tidak hanya teknik penggunaannya tetapi cara menyajikan informasi dengan komunikatif menggunakan media power point. Pentingnya pengetahuan ilmu berkomunikasi karena sangat erta kaitannya dengan kode etik serta estetika dalam menyampaikan presentasi.

Setelah peserta didik dibekali dengan Teknik penggunaan Ms Power Point, peserta diberikan tugas sebagai simulasi dalam penyajian informasi dengan menggunakan media power point. Materi yang presentasi berupa : profil pribadi, keindahan alam, dan hasil kebudayaan tertentu. Isi presentasi minimal 10 slide dan maksimal 20 slide. Selanjutnya, pada tahap ke-3 mereka menyampaikan presentasi sudah dibuat.

\section{HASIL DAN PEMBAHASAN}

Sebelum pelatihan dilaksanakan, ada beberapa persiapan yang dilakukan yaitu survei lapangan terkait kebutuhan serta persamasalah yang ada dilapangan, tepatnya di panti asuhan Yayasan otto Iskandar dinata, menentukan tema, penentuan jadwal pelatihan dan pembagian job description. Pelatihan dilaksanakan pada tanggal 15 April 2021 dengan tahapan sebagai berikut : 1) pemaparan materi oleh narasumber atau instruktur, 
728 Pelatihan Penggunaan Microsof Power Point dalam Meningkatkan Keterampilan Menyajikan Presentasi yang Menarik dan Interaktif - Gerry Sastro, Yulianti Rusdiana, Irvana Arovah, Fani Oktaviani, Anita Fujia, Dhea Rezky Febrianty, Novita Putri Amir, Intan Idaman Halawa DOI: https://doi.org/10.31004/abdidas.v2i4.299

2) simulasi pembuatan slide presentasi, serta 3) praktek dalam rangka menyampaikan presentasi yang sudah mereka buat. Setiap tahapan mereka ikuti dengan sangat antuasias karena mereka sangat menyukai sekali materi tersebut, karena instruktur selalu mengarakan pembuatan slide yang menarik yang dilengkapi dengan gambar, animasi dan video.

Dari hasil survei yang dilakkan setelah kegiatan setelai dilaksanakan, lebih dari $80 \%$ mereka menyatakan senang menggunakan power point dalam menyampaikan presentasi karena mereka tidak jenuh dan dalam menyampaikan informasi suasana selalu hidup. Hasil presentasi yang mereka buat juga sangat menarik karena mereka menggunakan animasi, gambar, dan video sebagai ungkapan ekspresi senang mereka dalam belajar.

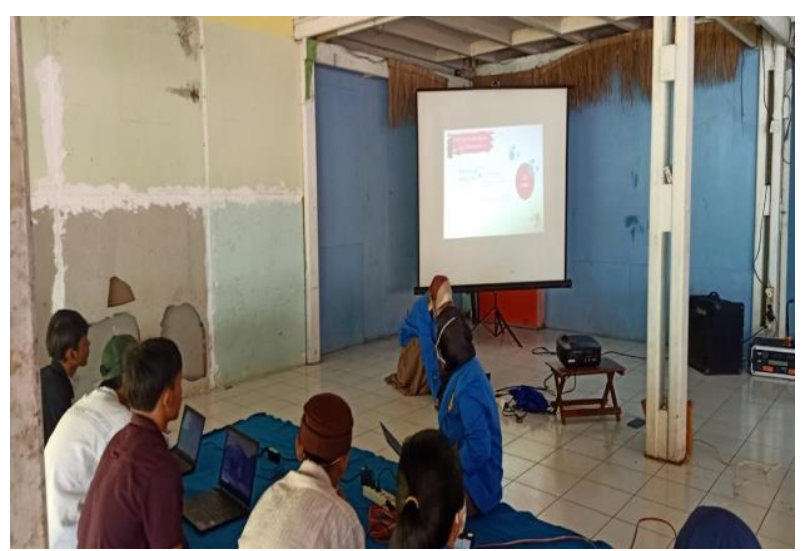

Gambar 1. Proses Pelatihan

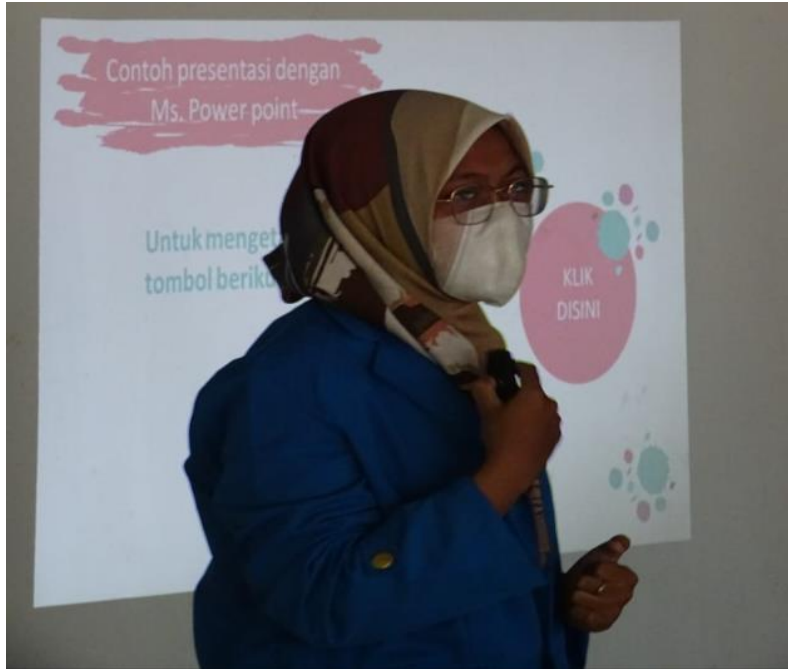

Gambar 2. Instruktur sedang menjelaskan Ms Powert Point

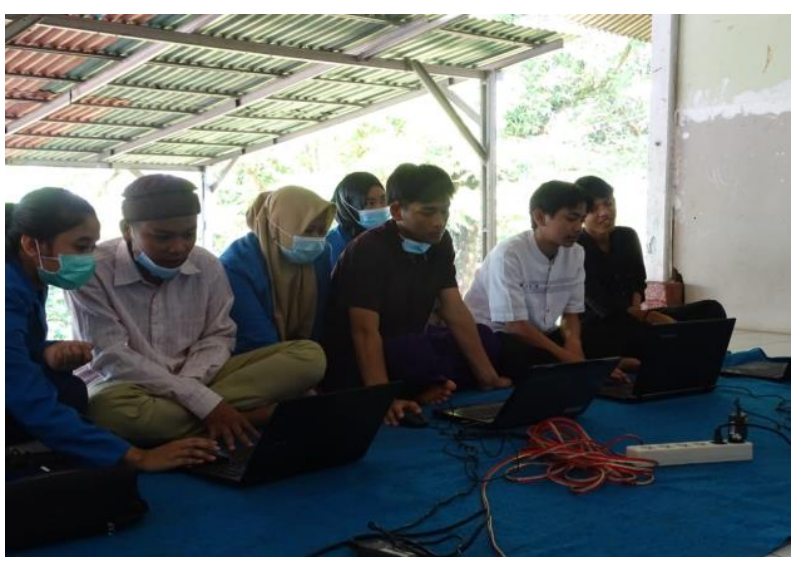

Gambar 3. Peserta Pelatihan sedang Mendemostrasikan Pembuatan Presentasi

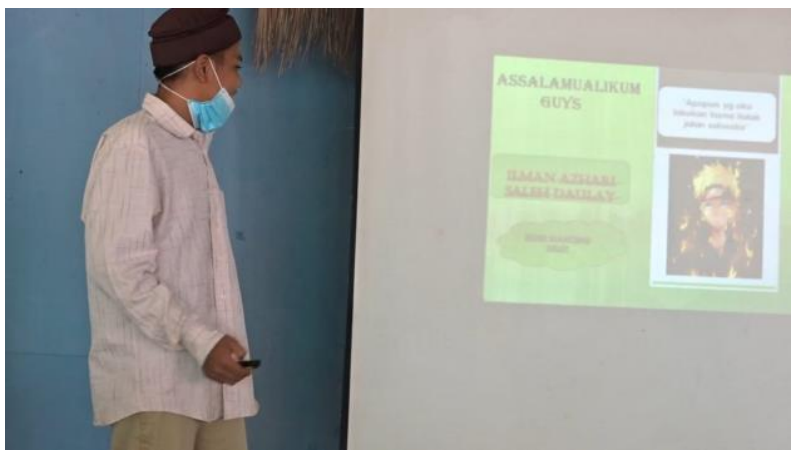

Gambar 4. Salah Seorang Peserta Sedang Presentasi 
729 Pelatihan Penggunaan Microsof Power Point dalam Meningkatkan Keterampilan Menyajikan Presentasi yang Menarik dan Interaktif - Gerry Sastro, Yulianti Rusdiana, Irvana Arovah, Fani Oktaviani, Anita Fujia, Dhea Rezky Febrianty, Novita Putri Amir, Intan Idaman Halawa

DOI: https://doi.org/10.31004/abdidas.v2i4.299

\section{SIMPULAN}

Dari hasil evaluasi capaian kemajuan pelaksanaan pengabdian kepada masyarakat dapat ditarik kesimpulan:

1. Pelatihan penggunakan Microsoft power point dapat meningkatkan keterampilan pesreta didik dalam menyajikan informasi.

2. Lebih dari $80 \%$ peserta menyatakan sangat senang dan bersemangat menggunakan power point.

Dengan keterbatasan waktu yang dimiliki tentukan kami menyadari belum seuruhnya konsep penggunaan power point yang disampaikan seperti penggunaan hyperlink dan lain-lain. Pada pengabdian berikutnya kami menyarankan untuk melanjutkan pelatihan melalui pengabdian kepada masyarakat, sehingga peserta didik mampu menggunakan power poin dengan maksimal.

\section{UCAPAN TERIMA KASIH}

Kegiatan ini berjalan dengan baik berkat bantuan dan dorongan yang cukup luar biasa dari berbagai pihak, rasa hormat dan terima kasih kami sampaikan kepada, Rektor Universitas Pamulang, Ketua LPPM Universitas Pamulang serta pengurus Yayasan Panti Asuhan Otto Iskandar Dinata.

\section{DAFTAR PUSTAKA}

Herliandry, L. D., Nurhasanah, N., Suban, M. E., \& Kuswanto, H. (2020). Pembelajaran Pada Masa Pandemi Covid-19. JTP - Jurnal Teknologi Pendidikan, 22(1), 65-70. https://doi.org/10.21009/jtp.v22i1.15286

Ilmadi, Aden, Sastro, G., Rusdiana, Y., \& Isnurani. (2020). Pelatihan penggunaan moodle untuk mengoptimalkan pembelajaran secara online.
Jurnal Abdidas, 1(6), 592-596. https://abdidas.org/index.php/abdidas/article/ view/128

Isnurani, Ilmadi, Aden, Sastro, G., Valentika, N., Nurbaiti, D., Sugianti, D., Lestari, P. I., Oktavian, S., Maesaroh, S., Nurmelani, V., Zufikar, P., Matematika, P., \& Pamulang, U. (2021). Jurnal abdidas. 2(1), 121-126.

Juanita, S., Hayati, P., \& Sakti, D. V. S. Y. (2019). Peningkatan Keterampilan Menyajikan Presentasi Menarik Dan Interaktif Bagi Guru Pkbm Negeri 27 Petukangan Dengan Pelatihan Microsoft Power Point. Sebatik, 23(2), 528-533. https://doi.org/10.46984/sebatik.v23i2.810

Kusuma, J. W., \& Hamidah, H. (2020). Perbandingan Hasil Belajar Matematika Dengan Penggunaan Platform Whatsapp Group Dan Webinar Zoom Dalam Pembelajaran Jarak Jauh Pada Masa Pandemik Covid 19. JIPMat, 5(1). https://doi.org/10.26877/jipmat.v5i1.5942

Simanjuntak, P., \& Handoko, K. (2019). Pembinaan Pemanfaatan Teknologi Informasi Dan Komunikasi Pada Masyarakat Pulau Temoyong Batam Kepulauan Riau. MATAPPA: Jurnal Pengabdian Kepada Masyarakat, 2(1), 20. https://doi.org/10.31100/matappa.v2i1.303 